\title{
Revisiting A Theory of Access: A Review
}

Rodd Myers a,c,d,* and Christian Pilegaard Hansen b

aSchool of International Development. Global Environmental Justice Group, University of East Anglia, Norwich, United Kingdom

bDepartment of Food and Resource Economics, University of Copenhagen, Denmark

cThe Dala Institute, Jakarta, Indonesia

dThe University of Gadjah Mada Faculty of Forestry, Yogyakarta Indonesia

* Corresponding author at r.myers@dala.institute

\section{Citation \& Copyright}

This is a pre-formatted version of the paper, which the authors are licensed to distribute and archive. Citation and copyright should follow the published version of the paper in Society \& Natural Resources. Publication information can be found here: http://dx.doi.org/

10.1080/08941920.2018.1560522.

\section{Keywords}

access, power, natural resources-environmental sociology

\begin{abstract}
A Theory of Access (Ribot and Peluso 2003) was published 15 years ago. With almost 1600 publications citing it, the paper is instrumental in expanding scholarly thinking beyond property by exploring notions of power. We reviewed all available literature that cited $A$ Theory of Access to understand its influence on academic literature. We first analyse literature in relation to other frameworks with similar concerns: (1) entitlements framework, (2) sustainable livelihoods approach, (3) powers of exclusion; and subsequently move to a review of how it has been engaged in broader theoretical and conceptual debates in the social sciences: (4) gender, (5) materiality, (6) property and authority, and (7) power. The analysis shows most of the literature interacts with $A$ Theory of Access superficially. Substantial attempts to address $A$ Theory of Access were varied and often used it to develop other social theory rather than to modify $A$ Theory of Access.
\end{abstract}

\section{Introduction}

A Theory of Access (Ribot and Peluso 2003) was published 15 years ago. The paper was instrumental in expanding scholarly understandings of access. Access emerges within power structures and has to do with the abilities of actors to benefit from 'things'. Ribot and Peluso placed differential relations among actors, and the 'things' they want to benefit from and control, at the centre of their theory. Ribot and Peluso synthesised several strands of thought in human geography, political economy and political ecology based on social theory and years of primary research.

The authors used considerations of relations of production building on Marx (1973) and Polanyi (1945) to respond to common property scholarship of Berkes (1989), Schlager and Ostrom (1992) and others (see Ribot and Peluso 2003, $156 \& 158$ and Kashwan, this issue). They were informed by the critique of common property literature (new institutional economics) as being ahistorical and apolitical and lacking power dimensions in its assumptions of methodological individualism (Peters 1993; Forsyth and Johnson 2014; Cleaver 2002). The 
work of Berry (1994; 1989) shaped the authors' notions of 'access'. Power in the context of property relations was informed by Weber's (1978) work on domination and Lund's (1994) and Berry's (1994) contributions on access control. Leading up to the publication of $A$ Theory of Access, Ribot had been working on participation in markets and democratic processes and Peluso had been publishing on forest power politics.

A Theory of Access took the literature based on MacPherson (1978) in which property is associated with enforceable claims to some use or benefit sanctioned by politico-legal authority, but expanded it to encompass a broader range of actors, structural and social relations, including the illicit. As Ribot and Peluso $(2003,157)$ explain, "our move from concepts of property and tenure to access locates property as one set of factors (nuanced in many ways) in a larger array of institutions, social and politicaleconomic relations, and discursive strategies that shape benefit flows". Bringing together these sociological, anthropological and geographical works toward a multi-disciplinary approach to access, Ribot and Peluso (2003, 154) focussed on access as an "ability, rather than rights as in property theory, this formulation brings attention to a wider range of social relationships that can constrain or enable people to benefit from resources without focusing on property relations alone." One of the most compelling features of $A$ Theory of Access is that it engages with both structure and agency while integrating rich empirical works with social science theory. Further, by leaving understandings of power as flexible, the theory has broad appeal. These are critical ingredients in attracting many scholars to the paper.

Approaching 1600 citations (Google Scholar February 28, 2018), scholars continue to draw on this work to better understand how actors benefit from 'things'. With this review paper, we analyse and discuss the ways in which $A$ Theory of Access has been used and applied. Specifically, we investigate how $A$ Theory of Access has interacted with, and influenced, other frameworks, concepts and theories within the social sciences. Moreover, and related, we review the critiques and suggestions for extensions of the theory. We ask in what ways the literature engages with $A$ Theory of Access and to what effect.

We structure this review in seven inductively constructed themes according to what we consider to be the most compelling, and the most voluminous theoretical intersects in the literature. We first engage with $A$ Theory of Access in relation to other frameworks with similar concerns: (1) entitlements framework, (2) sustainable livelihoods approach, (3) powers of exclusion; and subsequently move to a review of how it has been engaged in broader theoretical and conceptual debates in the social sciences: (4) gender, (5) materiality, (6) property and authority, and (7) power. These themes obviously intersect, and specific reviewed sources qualify under more than one heading, but they do the job of creating a structure. We conclude by reflecting on the works we review and considering the epistemological challenge of concatenating $A$ Theory of Access with other social theory.

\section{Methods}

We analysed sources (as at May 30,2017) that cited $A$ Theory of Access. We used 'cited by' in Google Scholar to identify references for all 1356 publications that have cited $A$ Theory of Access and included 1144 as available for review. That is, they were available online and we had access through the paywall and not duplicates (items by the same title - e.g. book chapter, conference paper, or working paper and journal article). We analysed publications in languages in which we are proficient: English, French, Spanish, Danish, and Indonesian. Only five publications were excluded due to language. Table 1 shows the types of publications that we included. We considered all literature items, including journal articles, books and book chapters, conference papers, working papers, masters and $\mathrm{PhD}$ dissertations, other academic works (for example lecture notes) and grey materials (published for non- 
academic purposes, often from civil society groups and so on). Almost half of the publications were journal articles, and just over a quarter were masters and doctoral theses.

We then used protocols to assign intensity of the use of $A$ Theory of Access as follows: (1=low) cited only or made a cursory citation to some aspect of the theory, $(2=$ medium $)$ used in analysis (access mapping), and ( $3=$ high) critique of $A$ Theory of Access and/or used it together with other theories to build on theory. The authors and one assistant assigned intensity values using a guide sheet, and the lead author spot checked the work of the other reviewers to ensure consistency. Inconsistencies were discussed among the authors.

The high-intensity literature items were all analysed by both authors for how they engaged with $A$ Theory of Access, to examine what aspects of the theory are built upon and/or critiqued, and against or toward what bodies of literature. Literature items that claimed robust engagement with $A$ Theory of Access but delivered only superficial analysis were subsequently downgraded to medium intensity. The low and medium intensity literature items were not explored further.

Table 1: Included publications by type and intensity level

\begin{tabular}{|l|r|r|r|r|r|}
\hline Publication Type & Intensity 1 & Intensity 2 & Intensity 3 & Total (\#) & Total (\%) \\
\hline Journal Article & 445 & 70 & 14 & 529 & $46.24 \%$ \\
\hline Thesis & 199 & 85 & 18 & 302 & $26.40 \%$ \\
\hline Work & 115 & 18 & 3 & 136 & $11.89 \%$ \\
\hline Book & 84 & 9 & 5 & 98 & $8.57 \%$ \\
\hline Other & 40 & 2 & & 42 & $3.67 \%$ \\
\hline Grey & 35 & 2 & & 37 & $3.23 \%$ \\
\hline Grand Total & $\mathbf{9 1 8}$ & $\mathbf{1 8 6}$ & $\mathbf{4 0}$ & $\mathbf{1 1 4 4}$ & $\mathbf{1 0 0 . 0 0 \%}$ \\
\hline Share (\%) & $\mathbf{8 0 . 2 4 \%}$ & $\mathbf{1 6 . 2 6 \%}$ & $\mathbf{3 . 5 0 \%}$ & $\mathbf{1 0 0 . 0 0 \%}$ & $\mathbf{1 0 0 . 0 0 \%}$ \\
\hline
\end{tabular}

Table 1 shows that $80 \%(n=918)$ of sources were 'low intensity', $16 \%(\mathrm{n}=186)$ were 'medium intensity', and 3.5\% (n=40) 'high intensity' publications. High intensity publications were mostly dissertations. The reviewed works covered a broad range of subject matter including abortion politics, affordable housing, water politics, resources of war, migration, citizenship, public services, and of course natural resources. We assigned up to two subject areas per publication from a list of subject areas that we developed iteratively. We found that $88 \%(\mathrm{n}=35)$ of the high-intensity publications and $79 \%(n=904)$ of all publications dealt with natural resources, land or agriculture. $25 \%(n=286)$ of all included publications had the word 'land' in the title, $22 \%(n=252)$ had the word 'forest', and 18\% $(n=206)$ had the word 'livelihood'. We also recorded the geographical areas of research and institutional affiliations when they were clearly available. $31 \%(n=349)$ of the publications focussed on Sub-Saharan Africa, and 25\% $(n=284)$ on South and Southeast Asia. The geographical focus of the high-intensity publications was similar to the entire collection with 30\% $(\mathrm{n}=12)$ in Sub-Saharan Africa and $20 \%(\mathrm{n}=8)$ in South and Southeast Asia. Almost $24 \%(n=237)$ of the publications were by first authors in the United States of America followed by Netherlands $(9 \%$ [n=95]) and the United Kingdom ( $9 \%[n=91])$. The United 
Kingdom and United States produced the largest number of high-intensity publications, both at $22 \%(\mathrm{n}=8)$ followed by Denmark $(11 \%$ $[\mathrm{n}=4])$, Canada ( $8 \%[\mathrm{n}=3])$, showing that no one country dominates the literature working with $A$ Theory of Access.

We indicate the works included in the review by appending a ' + ' to distinguish them from other sources that we use in our discussion. We have, as much as possible, attempted to integrate all papers that met our 'high intensity' threshold, but some sources and concepts were difficult to place within the flow and organisational logic of the paper. Works we would have liked to explore more, had we the place for them, included those emphasising the need to incorporate temporal dimensions of access (Berg 2008+; Rytteri and Sawatzky 2013+), nonmaterial 'green' commodity applications of access (Neimark, Mahanty, and Dressler 2016+), resilience and access (Langridge, Christian-Smith, and Lohse 2006+), emancipatory perspectives on access (Ribot 2014+), Faye and Ribot (2017+) on access an vulnerability, Boche $(2014+)$ on polycentricity of institutions that control and influence corporate land deals in Mozambique, and Pedersen $(2016+)$ on the importance of considering polycentricity in governance arrangements on landholdings in Tanzania.

\section{A Theory of Access and related theoretical frameworks}

We commence by reviewing the relationship between $A$ Theory of Access and closely related frameworks, namely those of entitlements, sustainable livelihood approach and powers of exclusion, and how various authors have combined them.

\section{A Theory of Access and the entitlements framework}

Amartya Sen (1981) developed the entitlements analysis to explain how food deficits can occur in situations where aggregate food supplies are sufficient. Focussing on how particular individuals and groups of people are susceptible to hunger and poverty, he introduces the concepts of endowments, entitlements and capabilities (Leach, Mearns, and Scoones 1999). Entitlements are defined as: "the set of alternative commodity bundles that a person can command in a society using the totality of rights and opportunities that he or she faces" (Sen 1994, 497). These entitlements are established from a person's endowments ('ownership'), e.g. over land and labour. Finally, capabilities are the capacity for doing valued things, that is, "the various 'beings and doings' that a person can achieve with his or her economic, social, and personal characteristics" (Dréze and Sen 1989, 12).

Leach et al. (1999) suggested an extended entitlements approach, the environmental entitlements framework, to address perceived shortcomings in Sen's approach. The key point of critique is that Sen is primarily concerned with control over resources through markets, supported by formal legal property rights (Leach, Mearns, and Scoones 1999, 233). By doing so, Sen's entitlements framework occludes non-legal, extra-legal and illegal forces by which an agent can obtain different bundles of commodities (Ribot 2014, 682+). Consequently, Leach et al. (1999) extended the entitlements framework to a broader range of formally legal and socially sanctioned institutional mechanisms by bringing in the notion of legal pluralism (see also von BendaBeckmann 1981). They define environmental entitlements as "alternative sets of utilities derived from environmental goods and services over which social actors have legitimate effective command and which are instrumental in achieving well-being" (Leach, Mearns, and Scoones 1999, 233).

Ribot and Peluso (2003) reference the entitlements framework only in a footnote. There is no explicit attempt to address how entitlements; in particular, the extended environmental entitlements framework of Leach et al. (1999), has influenced the conceptualisation of access and what are the similarities and differences between the 
entitlements framework and $A$ Theory of Access (Williams 2013). Yet, sources who cite Ribot and Peluso (2003) also frequently make reference to entitlements; highlighting the closeness of subject matter. As an illustration, 33 of the 40 sources $(83 \%)$ we classified as 'high intensity' also cited Leach et al. (1999).

Weigelt $(2014,83+)$ suggests that $A$ Theory of Access and the environmental entitlements framework share the pedigree of offering a "coherent conceptualisation of ways of accessing resources that are not sanctioned by rights... [and]... to approach the question of what people can do with their rights". We argue that by defining entitlements as 'legitimate effective command', the environmental entitlements framework, while broader than Sen's original concept, maintains a focus on property (see also discussion below on access, property and authority). A Theory of Access envisages a broader range of structural and relational mechanisms, including but not limited to property, that determine how access is gained, maintained or controlled. Moreover, by focusing on abilities and the ability to benefit, which may be interpreted in various situations and contexts to encompass both endowments, entitlements and capabilities, we consider $A$ Theory of Access to constitute a more flexible analytical construct than the environmental entitlements framework.

Several authors have attempted to integrate the two. However, while these studies provided for rich and solid empirical analysis, we found that the task of integration proved elusive.

Calderon Contreras (2011+), with an empirical focus on land reform in Mexico, suggests that (relative to an entitlements approach), A Theory of Access allows for a clearer understanding of the mechanisms that shape the distribution of benefits. He argues that this is accomplished by encouraging a focus on a single resource and the many mechanisms to benefit from that resource. Calderon Contreras contrasts this with the environmental entitlements perspective in which, "institutions influence control over all kinds of productive resources and the transformation of endowments into entitlements" (p 15). Based on this assertion, he proposes an extended access analytical framework with integration of $A$ Theory and Access and the environmental entitlements framework. Calderon Contreras uses the entitlements framework's focus on social differentiation to nuance how actors are able to use mechanisms of access to benefit from things (as they are called in the access literature- or endowments in the entitlements literature).

Aguirre (2013+) researches gender dynamics and land use change in Afro-descendant communities in Colombia. She aims to integrate entitlements, property and access theories to develop a deeper assessment and understanding of power relations in land use change. The analysis is an empirically rich and sound work, involving a detailed gender-based mapping of mechanisms of access. Hicks (2013+) and Hicks and Cinner (2014+) construct a theoretical/analytical framework that combines the entitlement framework with the mechanisms of access proposed by Ribot and Peluso (2003). They apply the framework to assess benefits (conceptualised as ecosystem services) from coral reefs. What the constructed framework does is to replace the 'institutions' that shape people's entitlements (Sen 1981; Leach, Mearns, and Scoones 1999) with the 'mechanisms of access' of Ribot and Peluso (2003). In our reading, this turns the framework and the resulting empirical work into something identical to $A$ Theory of Access and access mapping. The framework combines access and entitlements, but does not extend either of them considerably.

\section{A Theory of Access and the Sustainable Livelihoods Approach}

The Sustainable Livelihoods Approach (SLA) (Chambers and Conway 1992) was developed and gained popularity about a decade before $A$ Theory of Access was published. SLA encompasses five components: (i) the livelihood resources/capitals (the asset pentagon) which are mediated by (ii) institutions and organisations that subsequently shape (iii) livelihood strategies and ultimately generate 
(iv) livelihood outcomes; all playing out in (v) a specific context of conditions and trends (the vulnerability context) (e.g. Scoones 2015). SLA, like the entitlements framework and $A$ Theory of Access, pays attention to both structure and agency. SLA is not cited in $A$ Theory of Access, but Ribot in a later work explains that: "In lieu of social capitals, Ribot and Peluso (2003) use the language of identities, social status and social relations as a key part of 'access"' (Ribot 2014, 688+), thereby attesting to the above-suggested similarity between the two frameworks. In the same paper, he also ties the power dimensions of $A$ Theory of Access (see also discussion below) to 'vulnerabilities' and the vulnerability context; central elements in the SLA literature.

One of the main critiques of SLA is that it often lacks a power dimension in application if not in theory (De Haan and Zoomers 2005; Scoones 2015; King 2011; Scoones 2009). That is, SLA includes power dimensions nested within the 'capitals', 'institutions and organisations', and the 'context'. However, in practical applications these power dimensions are often neglected or treated in a cursory manner. Along similar lines, (Ribot 2014, 683+) asserts, "If not fully theorized, the household models may also miss broader structural relations of production and exchange within markets and a globalized system that shape broader-scale distributions." Along similar lines, (Scoones 2015, 46+) states, "a central but often missed feature of livelihoods frameworks and analysis is the role of institutions, organizations and policies in mediating access to livelihood resources and defining the opportunities and constraints of different livelihood strategies". In this work, he dedicates a chapter to 'access and control' in which he emphasises both $A$ Theory of Access and Hall et al. (2011+) (see discussion below).

Another critique of the SLA relates to its focus on the household as the basic unit of analysis and its assumption that the household is an uniform unit with common interests (Chambers 1987; Solesbury 2003) thereby failing to account for differential interests and powers within the household (Ribot 2014+). This gap makes fertile ground for integration with access theory, which holds power as a central tenet (see section below for more) and can accommodate differences among individuals both inter- and intra-households.

In our review, we met several sources that posited ambitions to integrate SLA and $A$ Theory of Access. Berg (2008+) explored relationships between livelihoods and access in his work on irrigation organisations in Nepal. Besta (2013+) looked at livelihood outcomes in the case of seaweed farming in Tanzania through a lens of $A$ Theory of Access, SLA and Sen's Co-operative Conflict Model (Sen 1987) and with a special emphasis on gender. We found that there is significant interest among scholars to fit $A$ Theory of Access with SLA, but were struck by how challenging this fit is in practice. We reflect on this more in our conclusions.

\section{A Theory of Access and the Powers of Exclusion}

Hall et al. (2011+) in their book Powers of Exclusion focus on the changing ways that people are excluded from land in SE Asia. Their work is inspired by Marxist notions of enclosure and primitive accumulation including Harvey's (2003) accumulation by dispossession. Hall et al. (2011+) take a point of departure in $A$ Theory of Access and see exclusion as the inverse of access; that is, exclusion is defined as "the ways in which people are prevented from benefiting from things" (see also D. Hall 2015+). They emphasise that inclusion has a double edge because some form of exclusion of some actors is a necessary precondition for other actors for deriving sustained benefits from, in this case, land. Hall et al. $(2011,7+)$ stipulate three main types of exclusions: "i) the ways in which already existing access to land is maintained by the exclusion of other potential users; ii) the ways in which people who have access lose it; and iii) the ways that people who lack access are prevented from getting it." These types are closely related to the notions of gaining, maintaining and controlling access in $A$ Theory of Access. The first type is, by 
implication, identical to Ribot and Peluso's (2003) access maintenance and control, the third is captured by access control and gaining access, while the second process is captured in the general dialectic and dynamics of access in A Theory of Access (Corbera 2012+; Myers 2012+; Beban and Gorman 2015+; see also Poteete [this issue]). But access is a broader concept than exclusion because no matter how well exclusion is enforced, there is no guarantee of benefits for any actor. As formulated by Baban and Gorman $(2015,2+)$, "[e]xclusion, is thus a necessary precondition for deriving sustained benefit from the land. But it is not a sufficient condition. There is for example, little to be gained from an empty field, at least in the immediate moment, no matter how well one might exclude others from it."

Hall et al. $(2011+, 15)$ suggest, parallel to the mechanisms of access in Ribot and Peluso (2003), four 'powers of exclusion': regulation ("It is not allowed"), force ("I'll get hurt if I try"), markets ("I can't afford it"), and legitimation ("It's wrong"). Like the mechanisms of access, the powers of exclusion may be combined and they intersect. The first, regulation, resembles the mechanism of property as used by Ribot and Peluso (2003) but here used in the opposite way. The second power, force, is perhaps where the Powers of Exclusion makes the most significant contribution to the mechanisms proposed by $A$ Theory of Access. Hall et al. (2011+) suggest that use of force, that is coercive power or the threat of using it, while not entirely absent, is under-emphasised by Ribot and Peluso (2003), who only discuss it under 'illicit access'. The third power, the market, with its emphasis on the price of land, is similarly represented in Ribot and Peluso (2003). Finally, the power of legitimation takes us from a structural (neoMarxist) power perspective to a more poststructuralist view (see discussion of power below). Ribot and Peluso (2003) have similar considerations under "access to knowledge".

In sum, we consider Hall et al.'s (2011+) powers of exclusion a highly relevant framework for analysing and understanding contestations over land and land exclusion, in line with the purpose for which it was constructed, but perhaps less relevant for other situations, because the powers are so specifically tied to land contestations. In comparison, A Theory of Access appears as a more generic framework. This said, and as we have discussed above, there is a fairly close connection between the suggested powers of exclusion and the mechanisms of access. The emphasis on the deliberate use of force as one of the powers could be seen as an important elaboration to the mechanisms suggested by $A$ Theory of Access.

We conclude this section by a discussion of Fairbairn (2013+) in which the author links $A$ Theory of Access and exclusion that does not rely on Hall et al.'s powers of exclusion framing. Fairbairn (2013+) makes an interesting contribution to the land grabbing debate in her study on Mozambique. She argues that rather than treating land grabbing as a top-down and driven by global markets or foreign states, that is a structural analysis focusing on the expanding and penetrating nature of capitalism, more attention should be paid to the crucial mediating role played by domestic elites. With a point of departure in A Theory of Access and with a specific focus on access control, she proposes a typology of powers of access control encompassing: i) traditional authority, ii) bureaucratic influence, iii) historical accumulation, iv) locally based business knowledge and networks, and v) control over the development agenda. She asserts that, "examining these sources of power clarifies why peasant dispossession is occurring despite the fact that peasant land property rights are protected by law" (Fairbairn 2013, 352+).

\section{A Theory of Access and key concepts in the social sciences}

In this section we review how scholars have engaged with $A$ Theory of Access in relation to key concepts and theories in the social sciences. We first review discussions on $A$ Theory of 
Access vis-à-vis gender and materiality and then move to discussions on access, property and authority and finish with access and power.

\section{A Theory of Access and Gender}

Gender relations have long been recognised as a major determinant of access to land and natural resources (Lawry et al. 2017; Carney and Watts 1990; Ribot and Peluso 2003). Gender, power and property are closely linked as power is exercised differently on women and men through property relations (Rocheleau and Edmunds 1997; Meinzen-Dick et al. 1997). A Theory of Access considers gender under 'access through social identity', but little more is said specifically about it. It is therefore not surprising that we found a number of innovative literature items that applied access mapping through a gender lens.

Among these are Aguirre (2013+) who undertakes a gendered analysis of access to land among Afro-descendant communities in the Pacific Region of Colombia. She attempts an analysis in three steps (benefits, mechanisms of access and bundles of powers) as proposed by Ribot and Peluso (2003) (see also "Access and Power").

Asaba (2013+), in her analysis of access to freshwater in Uganda, finds that children and women are constrained in their access to water by technologies, formal institutions, knowledge and information, as well as water usage fees or in-kind (labour) contributions. Despite the existence of 'improved' water sources in the study area, many women and children used 'unimproved' water sources that were physically closer, more reliable, and for which they did not have to pay repair or maintenance fees (page v).

Besta (2013+) in her gendered study of seaweed farming on Songo Songo Island, Tanzania, attempts to combine the Sustainable Livelihood Approach (see above), A Theory of Access, and Sen's Co-operative Conflict Model (Sen 1991) to analyse benefits from seaweed and power relations at the inter and intra-household level.
Khalid et al. (2015+) explores legal pluralism in the context of Pakistan, showing how women's rights are intertwined with notions of property, and specifically access to land. The authors show how custom takes precedence over religious values, and how civil laws are compromised while settlements are made in the name of customs, resulting in the denial of women's rights. They also make the case that male relatives use women, and their formal rights, as tools to gain access to land and other valuable resources.

Some authors have moved beyond a genderdisaggregated access analysis to a more fundamentally feminist perspective on access with a focus on women's empowerment. Goldman et al. (2016+) explore access and women's empowerment in Tanzania, finding that rather than outright land ownership, user rights to land, combined with access to knowledge and authorities, led to women's empowerment manifested in increased participation in political processes. The authors argue that it is especially the access to knowledge and authority that generated power and enhanced capabilities. A similar notion, that the ability to benefit from things is productive of more powers, is raised by Petitt $(2016+)$, citing Rao (2008). They argue that access is closely linked with self-esteem, personhood and self-worth, which make additional powers (capabilities) available to actors. These ideas related to the gendered ways in which power can be leveraged are important for understanding what the 'benefits' from 'things' means from feminist perspectives.

We see that recent developments in feminist political ecology may be fertile ground for advancing access theory by further unpacking power relations and thereby providing fresh and nuanced views on (mechanisms of) access. Aguirre $(2013,26+)$ calls for the "merging of feminist considerations of scale and embodiment to understand gender as a constitutive power at all scales of analysis" (Aguirre 2013, 26+; see also Wright 2010). Another contribution includes 
Nightingale (2011) who, in a case study from rural Nepal, illustrates the constant production and reproduction of subjectivities across gender, caste and class (intersectionality). Along similar lines, Elmhirst (2011+) studies migrants' access to agricultural land in Lampung, Indonesia and shows "how the negotiation of resource access is simultaneously a process of self-regulation and subject-making that draws on particular ideas about family and conjugal partnership, inculcating gendered and hetero-normative ideologies of the 'ideal citizen"' (p. 173). Sultana (2011+) studies access, control and conflict over household water in Bangladesh. She introduces the notion of 'emotional geographies', showing how the embodied emotions of women in charge of fetching water play a key role in the production of social relations of power and gendered subjectivities, hence suggesting emotions as a specific mechanism of access.

\section{A Theory of Access and Materiality}

A Theory of Access is squarely centred around the ability to benefit from 'things', but stops short of exploring how the 'thing' itself affects access. 'Things' have social meaning, as Ribot and Peluso (2003) explore, and affect social relations (Appadurai 1986). Ribot and Peluso (2003) stress the influence of the characteristics of the 'thing' on access, but do not go into details. Materiality is the appreciation that material, "the stuff that things are made of" (Ingold 2007, 1), and "things other than humans make a difference in the way social relations unfold" (Bakker and Bridge 2006, 1617). Materiality considers not only the 'thing' (biophysical) but also the geographical characteristics in which the thing, and humans are situated. Ribot $(1998,310)$ mentions "physical circumstance (location or stature)" as a mechanism of access that would affect how an actor could benefit from Senegal's charcoal commodity chain, but this is not reflected in Ribot and Peluso (2003) A considerable body of literature deals with how materiality affects social relations (eg. Barham, Bunker, and O’Hearn 1994; Miller 1998; Boyd, Prudham, and Schurman 2001). In the body of works we reviewed, only a few publications stood out by developing access theory to include not only how actors affect things, but how things affect actors and actor relations. They point out that access theory requires a consideration of biogeophysical characteristics of the thing from which actors intend to benefit. Some authors have made attempts to tie materiality closer to $A$ Theory of Access.

Milgroom (2012+) shows how geographical distance is important for access. Dyke (2006+) shows how changing land use, involving road construction, affect access to non-timber forest products and they become accessible in more remote locations. Cardozo (2013+) makes the case for 'accessibility' constraints in the Amazon not only due to geographical distance, but the topographical challenges to accessing markets. Ginger et al. $(2012,703-4+)$ in their study of access to forest land in the US suggest that $A$ Theory of Access neglects biogeophysical dimensions of how actors benefit from things.

Along similar lines, Ellis (2016+) studies access to sweetgrass in coastal Maine finding that urban development affected the ability of the Wabanki people to benefit from the spiritual usage of sweetgrass.

Myers (2015+) explores access to rattan in Indonesia and found that the biogeophysical characteristics of rattan shaped who has the ability to benefit from it. The location of rattan resources in remote mountainous areas and the physicality of rattan shapes gender differences in access. Similarly, Besta $(2013,157+)$ in her study of access to marine resources in Tanzania, shows how "nature, in this case lunar tidal variations and trade winds, creates gendered access to marine resources" by creating physical conditions that, for cultural reasons, were more favourable to men.

There is therefore a call in the literature for a greater emphasis on how 'things' influence access. Materiality has a clearly important influence on access and, as Ribot (2014+) discusses with reference to climate change, can be an important mitigating factor of access. While the mechanisms of access are employed 
by actors, materiality is a state of a 'thing' independent of whether or not humans interact with it (unless one agrees with e.g. Latour 2005 that things themselves are also agents in the sense that they evoke the actions of actors). Either materiality has to be treated differently than mechanisms, framed in $A$ Theory of Access as something done by humans; or the conceptualisation of mechanisms has to be broadened to a more post-humanist perspective in which 'things' have agency (see also Ribot 2018).

\section{A Theory of Access, Property and Authority}

Perhaps the greatest contribution of $A$ Theory of Access is its emphasis on, and expansion of, other means than property through which benefits may be obtained. While not neglecting or downsizing the importance of right-based access, Ribot and Peluso (2003) provide a detailed discussion of property and why property cannot stand alone, and how other mechanisms, in addition to property and in combination with property, shape actors' ability to benefit. Ribot and Peluso (2003) shifted focus from rights-based approaches to more nuanced views on how actors gain, maintain and control access. Ribot and Peluso (2003) define property, in line with MacPherson (1978) and Bromley (1989), as an enforceable (or rather legitimised) claim to some use or benefit; property is only property if socially legitimate institutions sanction it.

In discussing the dialectics between access and property, Sikor and Lund (2009+) feature prominently among the sources we reviewed: 18 of 40 papers we classified as 'high-intensity' cited the paper. The paper discusses what the authors call the 'grey zone' between property and access. They state that property and access overlap partly because property may or may not translate into an ability to benefit. On the other hand, access may or may not result from property (Sikor and Lund 2009, 6+). This is in full accordance with Ribot and Peluso (2003). Moving on, they propose that, "competition over access can in many ways be seen as the forerunner of property contestations where people try to secure their possession with recognition from a politico-legal institution...and that [1] egitimization by a politico-legal authority emerges as the distinguishing factor between access and property" (Sikor and Lund 2009, 6+). Based on the discussion of the characteristics of access and property, Sikor and Lund (2009+) takes the argument one step further by suggesting a close link (they call it a 'contract') between property and authority: "The process of recognition of claims as property simultaneously works to imbue the institution that provides such recognition with the recognition of its authority to do so" (Sikor and Lund 2009, 1+). So, according to Sikor and Lund, access (and in particular property) analysis is not only about how wealth is distributed, but equally about how politico-legal institutions ('polities') emerge, consolidate and possibly collapse based on property and access relations, hence linking access (property) to processes of state-building (see also Rasmussen and Lund 2018).

The dialectics between access and property discussed by Sikor and Lund (2009+) have been taken up by a large number of scholars; some of whom also investigate the suggested link between access/property and authority empirically. We highlight two prominent examples in our 'high-intensity' sample: Milgroom (2012+) and Kronenburg García (2015+). Milgroom (2012+, see also Milgroom and Ribot, this issue) investigate the consequences of a resettlement programme in Mozambique that attempted to resettle people residing inside a national park to locations outside the park. She shows how the local village leader lost his authority in the resettled location because he no longer was in charge of land allocation and management. With reference to Sikor and Lund's contract between property and authority, Milgroom (2012+) suggests that the notion of a 'contract' should be expanded to a general relationship between access (control) and authority. The point is valid, and illustrates the thin line between access control (controlling the access of others) and granting property. 
In the other study that we want to highlight, Kronenburg García (2015+) investigates a struggle over land and authority in Loita, Kenya. Kronenburg García shows how the authority of traditional leaders hinged on their continued control over access to land and use of the forest. So like in the case of Milgroom $(2012+)$, this case also suggests a link between access control and authority, or if we go along with Sikor and Lund (2009+) between property and authority. This case also illustrates how customary leaders compete over authority with the state, international NGOs;institutions that the local leaders, paradoxically, also depend on for recognition and support (see also Ribot 2007; Ribot 2013; Ribot, Chhatre, and Lankinad 2008).

In summary, property is an integral element of $A$ Theory of Access and Ribot and Peluso (2003) situate property vis-a-vis and among other mechanisms by which actors are able to obtain benefits. The contribution of Sikor and Lund (2009+) adds additional insights into what distinguishes property and access, and, in a way, brings 'property back in'. Their suggestion of a reciprocal relationship between property and authority has wide implications and brings $A$ Theory of Access into dialogue with notions of state-building, the sources of political authority and how it comes about and vanish.

\section{A Theory of Access and Power}

Power is a fundamental concept in social sciences (Giddens 1984). Probably for the very same reason, power is among the most fraught and contested concepts (Derek Hall, Hirsch, and Li 2011+). With power and power relations being central elements of $A$ Theory of Access, it comes as no surprise that the Ribot and Peluso's (2003) use of power has been contested.

Before turning to the critiques and suggestions for expansion of power in $A$ Theory of Access it is useful to discuss how Ribot and Peluso $(2003,156)$ consider power. Centrally, they assert that:

Ability is akin to power, which we define in two senses- first, as the capacity of some actors to affect the practices and ideas of others (Weber 1978:53; Lukes 1986:3) and second, we see powers emergent from, though not always attached to, people. Power is inherent in certain kinds of relationships and can emerge from or flow through the intended and unintended consequences or effects of social relationships. Disciplining institutions and practices can cause people to act in certain ways without any apparent coercion (Foucault 1978 a; Foucault 1979).

They further suggest that actors have more power in some relationships than in others, and at particular points of time (p. 158). Different people and institutions can draw on or hold different 'bundles of powers', which include various means, processes of, and relations for, gaining, maintaining and controlling access (pp. 159-160). By drawing on the works of Weber and Lukes, Ribot and Peluso (2003) adhere to an actor-oriented power perspective. That is, actors possess agency and they in various ways exercise or harness power in an attempt to achieve particular outcomes (benefits). In this undertaking, they may be met by opposition from other, more powerful actors and structural limitations set by institutions (Svarstad et al. 2018). At the same time, by making reference to the work of Foucault, $A$ Theory of Access also features a more poststructuralist view on power. Central here is the role of discursive power whereby some actors produce discourses, understood as a socially shared perspective on a topic, and are able to get other actors to adopt and reproduce the discourse (Svarstad et al. 2018). This view on power is most clearly expressed in A Theory of Access in the discussion of 'access to knowledge" (pp. 168-169). Finally, A Theory of Access makes reference to, and is clearly inspired by Marxist political economy and Marxist power perspectives, that is, a focus on human agency being constrained by historically established (class) structures produced by a capitalist mode of production (Svarstad et al. 2018, Harvey 2003). 
Various authors have critiqued the treatment of power in $A$ Theory of Access and suggested expansions. Westermann $(2007+)$ critiques Ribot and Peluso (2003) for not discussing "....specifically or in detail their definition of power nor do they position themselves in an in depth theoretical discussion of power" (p. 71). Further, Westermann (2007+) suggests that the access framework and its 'bundles of power' (mechanisms) can be productively related to Bourdieu's concepts of praxeology, social fields and capitals (Bourdieu and Wacquant 1992). Westermann (2007+) proposes that $A$ Theory of Access serves as a useful guide for empirical data collection, mainly referring to the typology of access mechanisms, while Bourdieu's praxeology serves as an analytical framework for understanding how data should be analysed and understood. He pursues this strategy in his empirical work on payments for watershed hydrological services in Tiquipaya Watershed, Bolivia.

Next, Koch (2008+) critiques $A$ Theory of Access for shortcomings and inconsistencies, primarily around the conceptualisation of access mechanisms, which she does not consider appropriately differentiate between 'structural' and 'relational', and for its treatment of power. She considers $A$ Theory of Access - despite its intention of the opposite - as a structural approach to access that does not adequately theorise agency (Koch 2008, 6+). She further critiques Ribot and Peluso (2003) for lacking clarity on the source of power by asking whether power is a product of negotiation or something possessed by the individual. She also suggests ambiguity in terms of the changing nature of power. However, as discussed above, in our reading Ribot and Peluso (2003) were not attempting to decorticate power, but to describe how it is mobilised, exercised and bundled in the processes of access.

Westermann (2007+) identifies an ambiguity in the treatment of the 'bundles of powers' in $A$ Theory of Access concerning analysis/mapping. Ribot and Peluso $(2003,161)$ say: “...access analysis involves 1) identifying and mapping the flow of the particular benefit of interest, 2) identifying the mechanisms by which different actors involved gain, control, and maintain the benefit flow and its distribution; and 3) an analysis of the power relations underlying the mechanisms of access involved in instances where benefits are derived". The ambiguity relates to the third step, the analysis of power relations, which seems to suggest yet another set, or layer, of 'powers' below the mechanisms, that is in a sense the 'sources' of the access mechanisms. While the two first steps are elaborated and discussed in details by Ribot and Peluso (2003), the third step remains underexplored. This is crucial given the large number of empirical studies, as documented by this review, that have used $A$ Theory of Access as their analytical framework and that have conducted access mapping, however stopping short of the third proposed step. In our review, we only found a few works which explicitly attempted to include the third step (see Aguirre 2013+; Weigelt 2014+).

Moving now from explicit treatments and critiques of the notion of power in $A$ Theory of Access towards works that in various ways have linked access and power, Kashwan (2015) is concerned with historically entrenched power asymmetries among actors. He uses empirical data from cases of forest decentralisation (and re-centralisation) in India to suggest that in order to understand institutional choices in one arena, there is a need for examining and understanding power asymmetries and access control in other, interlinked institutional arenas. He found that forest dwellers and their associations at the local level were not in a position to articulate opposition to institutional developments that go against their interests, e.g. requirements of forest patrols that puts high labor demands on the forest dwellers, because their access in other arenas is controlled by powerful agents, notably village leaders and the State Forest Department, and their access would be at risk if they attempted to resist in the forest arena. This brings the 'webs of access' discussed by Ribot and Peluso (2003) to the fore. Next, Hein $(2016+)$ examines the dynamics of access and evolving access mechanisms as a result of the implementation of 
REDD+ projects in Jambi, Indonesia. He suggests that access analysis will benefit from a consideration of powers and power differentials across multiple, connected scales. The REDD+ projects in Jambi reduced the ability of actors to access land for some, provided additional opportunities for others, and provided legitimacy for climate justice campaigns and organisations . Finally, Dorondel_(2008+) explores power, patronage and illegal forest access in Romania showing how the Rudaris made a living from working with wood from illegally felled trees without sanction through patronage relations with local elites who benefit from reduced prices of timber both legal and illegal.

In this section, we discussed the notion of power in A Theory of Access and have reviewed sources that made specific attempts to critique and/or enrich its concept of power. This is, of course, an incomplete account of the ways that authors have worked with notions of power in access literature, since power is at the very core of $A$ Theory of Access. In this way, all sources that engage robustly with $A$ Theory of Access address access and power in some way. We consider that Ribot and Peluso (2003) use a broad interpretation and understanding of power encompassing structural, actor-oriented and post-structuralist perspectives. It is exactly this broad conceptualisation of power that provides A Theory of Access flexibility to fit a range of applications in theory and in practice. What is perhaps missing from $A$ Theory of Access is a more explicit positioning and discussion of these power perspectives, as also noted by the critics. Finally, we suggest that there may be scope for further elaboration of the third step of the access mapping, that is, the power relations underlying the mechanisms of access.

\section{Conclusions}

Ribot and Peluso (2003) built their work on a strong tradition of accomplished scholarship. In our view, the key contribution of $A$ Theory of Access is its conceptual shift away from a prime focus on rights (property) by pointing out the varied and multiple mechanisms by which people gain, maintain and control access in addition to property. Access theory puts property in its place among other means of securing benefit. Second, A Theory of Access provides scholars and students with a useful framework for analysing and organising their empirical data in diverse fields ranging from abortion politics, affordable housing, water politics, resources of war, migration, citizenship, public services to natural resources. $A$ Theory of Access therefore clearly features great flexibility and applicability. This is testified by the fact that 226 studies in our sample used $A$ Theory of Access as an analytical framework for their analysis of empirical data. The influence of the paper is also evident in its ever-increasing number of citations.

The low proportion of literature items that engaged robustly with $A$ Theory of Access was in many ways unsurprising for us, especially considering that one of our hypotheses was that most citations of $A$ Theory of Access would exactly be for the definition of access. This is probably not unique for $A$ Theory of Access but appears to be a common feature for popular and often cited works. As an example, in a retrospective done by Oliver and Marwell (2001) on citations of their previous work on Critical Mass Theory, they suggested that although widely cited, the large majority of sources citing them failed to engage substantially with the theory.

In our assessment, $A$ Theory of Access offers a broader conceptualisation of access than the entitlements framework, even in Leach et al.'s (1999) extended version, and is more flexible, because 'abilities' may encompass both endowments, entitlements and capabilities. We found few applications that convincingly integrated the two. The Sustainable Livelihoods Framework, although also a widely used approach, has also proven elusive to operationalisation together with $A$ Theory of Access, although recent works by Scoones (2015+) aim to pull access and control into that framework. Similarly, Ribot (2014+) suggests that access analysis can help to answer why capitals or capacities may be lacking and how 
some actors have come to be more vulnerable than others. Likewise, $A$ Theory of Access appears to be a more flexible framework than the Powers of Exclusion with the latter more tailored to contestations over land. A contribution from Powers of Exclusion to $A$ Theory of Access may be considered to be its more explicit notion of force as a mechanism of access. Gender relations are considered in $A$ Theory of Access, yet a number of scholars have demonstrated how it can be applied explicitly in detailed studies of particularly women's access to resources. Moreover, recent political ecology scholarship has brought in feminist theory to help explain access, access mechanisms and power relations more robustly.

Scholars working on materiality have argued that there ought to more focus on the 'thing' and its biogeophysical characteristics, because it shapes social relations and consequently who benefits from 'things'. On access, property and authority, A Theory of Access has made an important contribution in emphasising a host of other mechanisms that influence access in addition to property. Sikor and Lund (2009) complements $A$ Theory of Access by discussing what is unique in property compared to other mechanisms of access and by suggesting and theorising a reciprocal link (or contract) between property and authority whereby politico-legal institutions gain recognition and authority by recognizing various actors' claims as property. Finally, we reviewed various contributions and critiques of the notions of power in A Theory of Access, but failed to find literature that convincingly suggested amendments or additions to its already pluralistic conceptualisation of power.. In sum, we found few substantial critiques and suggested enhancements to $A$ Theory of Access, but most significantly that it has influenced social theory through the broad body of literature that has used, and continue to use it as a basis for analysis.

Mouzelis (1995; see also Lund 2010) breaks theory into 'explanatory' and 'heuristic' frameworks. A Theory of Access clearly belongs to the latter, because it does not attempt a "systematic theory of the nature of man and society" as do explanatory frameworks such as works by Bourdieu and Foucault (Wright Mills 2000, 23; in Lund 2010, 26). Rather, A Theory of Access is heuristic: it provides a set of conceptual tools, notably its definition of access, the constructs of gaining, maintaining and controlling access, and the mechanisms of access that scholars can use to guide and structure empirical analysis. In this regard, it shares an epistemological compatibility with other frameworks discussed in this paper, notably the entitlements framework, the Sustainable Livelihoods Framework and the Powers of Exclusion. The heuristic nature of $A$ Theory of Access is testified by the large number of studies that have used it to guide their analysis of empirical data through access mapping. On the other hand, it should also be possible to integrate heuristics (such as $A$ Theory of Access) with more explanatory theory, but we found only few attempts to do so in the review. So here may be opportunities for future work.

Our contribution to scholarship in this paper is to analyse the works that have cited $A$ Theory of Access and demonstrate the ways that scholars have engaged with it. We have shown the range of scholarship that engages with Ribot and Peluso (2003) and the importance that it has had in reframing the way that actors are positioned to benefit from 'things', suggesting some gaps that could be used for future scholarship. We look forward to further developments of $A$ Theory of Access; some important ones, we believe, are found within this special issue.

\section{Acknowledgements}

This paper was the initiative of the authors and not explicitly funded by any source. Myers developed this paper while working on the ProdJus (Supranational Forest Governance in an Era of Globalising Wood Production and Justice Politics) research project funded by 
Riksbankens Jubileumsfond in collaboration with the Wellcome Trust and Volkswagen Stiftung through the Europe and Global Challenges initiative. Hansen while working on the AX (Access and Exclusion along the Charcoal Commodity Chain in Ghana) research project funded by the Danish Development Research Fund under the Danish Ministry of Foreign Affairs (project 14-03 KU). We appreciate the reflections on an early draft of the paper by Christian Lund and Jens Friis Lund, early coding that Anders M. Hallund conducted, some help from Nitya Rao with our reflections on gendered access analysis and feminist approaches, and the superb (and challenging) comments from three anonymous reviewers.

\section{References}

Aguirre, C.N. 2013. Work Streaming/mainstreaming Gendered Land Use and Land Cover Change (GLUCC): Afro-Descendant Communities in the Pacific Region of Colombia. PhD, University of Texas at Austin.

Appadurai, A. 1986. Introduction: Commodities and the Politics of Value. In The Social Life of Things. Cambridge: Cambridge University Press.

Asaba, R.B. 2013. Gender, Power and Local Water Governance in Rural Uganda. PhD, National University of Ireland Maynooth.

Bakker, K., and G. Bridge. 2006. Material Worlds? Resource Geographies and the Matter of Nature. Progress in Human Geography 30, no. 1: 5-27.

Barham, B., S.G. Bunker, and D. O'Hearn. 1994. Raw Materials Industries in Resource Rich Regions. States, Firms and Raw Materials: The World Economy and the Ecology of Aluminium: 3-39.

Beban, A., and T. Gorman. 2015. Gaining and Maintaining Control: Vietnamese Migrants, Cambodian Elites and Strategies of Land Control along the Cambodian Borderlands. In Land Grabbing, Conflict and Agrarian-environmental Transformations: Perspectives from East and Southeast Asia. Chiang Mai: Chiang Mai University.

von Benda-Beckmann, K. 1981. Forum Shopping and Shopping Forums: Dispute Processing in a Minangkabau Village in West Sumatra. The Journal of Legal Pluralism and Unofficial Law 13, no. 19 (January 1): 117-159.

Berg, T.R. 2008. Irrigation Management in Nepal's Dhaulagiri Zone: Institutional Responses to Social, Political and Economic Change. SPIRIT PhD Series.

Berkes, F. 1989. Common Property Resources, Ecology and Community Based Sustainable Development. London: Belhaven Press.

Berry, S. 1989. Social Institutions and Access to Resources. Africa, Quaderni 59, no. 1 (January): $41-55$.

- 1994. Resource Access and Management as Historical Processes-Conceptual and Methodological Issues. Occasional Paper 13: 24-45.

Besta, N.A. 2013. Seaweed Farming and Intra-Household Gender Relations on Songo Songo Island, Tanzania. $\mathrm{PhD}$, University of East Anglia.

Boche, M. 2014. Contrôle Du Foncier, Agricultures D'entreprise et Restructurations Agraires: Une Perspective Critique Des Investissements Fonciers à Grande échelle: Le Cas de La Partie Centrale Du Mozambique. Universite Paris-Sud.

Bourdieu, P., and L.J.D. Wacquant. 1992. An Invitation to Reflexive Sociology. Chicago: University of Chicago Press.

Boyd, W., W.S. Prudham, and R.A. Schurman. 2001. Industrial Dynamics and the Problem of Nature. Society \& Natural Resources 14, no. 7 (August 31): 555-570.

Bromley, D.W. 1989. Economic Interests and Institutions: The Conceptual Foundations of Public Policy. Oxford: Basil Blackwell.

Calderon Contreras, R. 2011. Access to Land-Based Resources under the Influence of Land Reform: 
A Case Study from an Agrarian Community in Mexico. $\mathrm{PhD}$, University of East Anglia.

Cardozo, M.L. 2013. Smallholder Livelihoods and Market Accessibility in the Peruvian Amazon.

$\mathrm{PhD}$, The University of Texas at Austin.

Carney, J., and M. Watts. 1990. Manufacturing Dissent: Work, Gender and the Politics of Meaning in a Peasant Society. Africa, Quaderni 60, no. 2 (April): 207-241.

Chambers, R. 1987. Sustainable Livelihoods, Environment and Development: Putting Poor Rural People First. Institute for Development Studies Discussion Paper 240.

Chambers, R., and G. Conway. 1992. Sustainable Rural Livelihoods: Practical Concepts for the 21st Century. Institute of Development Studies (UK).

Cleaver, F. 2002. Reinventing Institutions: Bricolage and the Social Embeddedness of Natural Resource Management. The European Journal of Development Research 14, no. 2: 11-30.

Corbera, E. 2012. Powers of Exclusion. Land Dilemmas in Southeast Asia. The Journal of Peasant Studies 39, no. 1: 221-224.

De Haan, L., and A. Zoomers. 2005. Exploring the Frontier of Livelihoods Research. Development and Change 36, no. 1 (January 1): 27-47.

Dorondel, S. 2008. They Should Be Killed': Forest Restitution, Ethnic Groups and Patronage in PostSocialist Romania. In The Rights and Wrongs of Land Restitution: "Restoring What Was Ours," ed. D. Fay and D. James. London: Routledge.

Dréze, J., and A. Sen. 1989. Hunger and Public Action. Oxford: Oxford University Press.

Dyke, A.J. 2006. The Practice, Politics and Ecology of Non Timber Forest Products in Scotland. PhD, University of Glasgow.

Ellis, A.M. 2016. Wabanki Access to Sweetgrass (Hierochloe Odorata) within Coastal Maine's Diminishing Open Land Tradition. PhD, University of Maine.

Elmhirst, R. 2011. Migrant Pathways to Resource Access in Lampung's Political Forest: Gender, Citizenship and Creative Conjugality. Geoforum; Journal of Physical, Human, and Regional Geosciences 42, no. 2 (March 1): 173-183.

Fairbairn, M. 2013. Indirect Dispossession: Domestic Power Imbalances and Foreign Access to Land in Mozambique. Development and Change 44, no. 2: 335-356.

Faye, P., and J. Ribot. 2017. Causes for Adaptation: Access to Forests, Markets and Representation in Eastern Senegal. Sustainability: Science Practice and Policy 9, no. 2 (February 20): 311.

Forsyth, T., and C. Johnson. 2014. Elinor Ostrom's Legacy: Governing the Commons and the Rational Choice Controversy. Development and Change 45, no. 5: 1093-1110.

Foucault, M. 1978. Governmentality. In The Foucault Effect, ed. G. Burchell, C. Gordon, and P. Miller, 87-104. Chicago: The University of Chicago Press.

- 1979. On Governmentality. London: Ideology Consciousness.

Giddens, A. 1984. The Construction of Society. Cambridge: Polity.

Ginger, C., M.R. Emery, M.J. Baumflek, and D.E. Putnam. 2012. Access to Natural Resources on Private Property: Factors beyond Right of Entry. Society \& Natural Resources 25: 00-715.

Goldman, M.J., A. Davis, and J. Little. 2016. Controlling Land They Call Their Own: Access and Women's Empowerment in Northern Tanzania. The Journal of Peasant Studies 43, no. 4: 777797.

Hall, D. 2015. Land's Essentiality and Land Governance. In Governing Access to Essential Resources, ed. K. Pistor and O. De Schutter. New York: Columbia University Press.

Hall, D., P. Hirsch, and T. Li. 2011. Powers of Exclusion. Singapore: NUS Press.

Harvey, D. 2003. The New Imperialism. Oxford: Oxford University Press.

Hein, J.I. 2016. Rescaling Conflictive Access and Property Relations in the Context of REDD+ in Jambi, Indonesia. PhD, Georg-August-Universität Göttingen.

Hicks, C.C. 2013. Ecosystem Service Values and Societal Settings for Coral Reef Governance. PhD, James Cook University.

Hicks, C.C., and J.E. Cinner. 2014. Social, Institutional, and Knowledge Mechanisms Mediate Diverse Ecosystem Service Benefits from Coral Reefs. PNAS 111, no. 50: 17791-17796.

Ingold, T. 2007. Materials against Materiality. Archaeological Dialogues 14, no. 1 (June): 1-16.

Kashwan, P. 2015. Integrating Power in Institutional Analysis: A Micro-Foundation Perspective. Journal of Theoretical Politics: 1-22.

Khalid, A., I. Nyborg, and B.N. Khattak. 2015. Whose Property Whose Authority? Gendering the Legal and Customary Practices in Ownership and Access to Land: A Case of Swat, Pakistan. Journal of Rural Studies 41: 47-58.

King, B. 2011. Spatialising Livelihoods: Resource Access and Livelihood Spaces in South Africa. 
Transactions of the Institute of British Geographers 36: 297-313.

Koch, J. 2008. Perspectives on Access to and Management of Natural Resources. DIIS Working Paper 8.

Kronenburg García, A. 2015. Contesting Control: Land and Forest in the Struggle for Loita Maasai Self-Government in Kenya. Vol. 58. African Studies Collection. Leiden: African Studies Centre.

Langridge, R., J. Christian-Smith, and K.A. Lohse. 2006. Access and Resilience: Analyzing the Construction of Social Resilience to the Threat of Water Scarcity. Ecology 11, no. 2.

Latour, B. 2005. Reassembling the Social: An Introduction to Actor-Network-Theory. Oxford: Oxford University Press.

Lawry, S., C. Samii, R. Hall, A. Leopold, D. Hornby, and F. Mtero. 2017. The Impact of Land Property Rights Interventions on Investment and Agricultural Productivity in Developing Countries: A Systematic Review. Journal of Development Effectiveness 9, no. 1 (January 2): 6181.

Leach, M., R. Mearns, and I. Scoones. 1999. Environmental Entitlements: Dynamics and Institutions in Community-Based Natural Resource Management. World Development 27, no. 2 (February 1): $225-247$.

Lukes, S. 1986. Power. New York: New York University Press.

Lund, C. 1994. Tinkering Methodology. Access, Control and Management of Natural Resources in Sub-Saharan Africa-Methodological Considerations. Occasional Paper 13: 10-23.

. 2010. Approaching Development: An Opionated Review. Progress in Development Studies 10, no. 1 (January 1): 19-34.

Macpherson, C.B. 1978. Property, Mainstream and Critical Positions. Toronto: University of Toronto Press.

Marx, K. 1973. Grundrisse. Trans. Martin Nicolaus. London: Penguin.

Meinzen-Dick, R.S., L.R. Brown, H.S. Feldstein, and A.R. Quisumbing. 1997. Gender, Property Rights, and Natural Resources. World Development 25, no. 8 (August 1): 1303-1315.

Milgroom, J. 2012. Elephants of Democracy. PhD, Wageningen University.

Miller, D. 1998. Material Cultures: Why Some Things Matter. Chicago: University of Chicago Press.

Mouzelis, N. 1995. Sociology Theory: What Went Wrong? Diagnosis and Remedies. London: Routledge.

Myers, R. 2012. Powers of Exclusion: Land Dilemmas in Southeast Asia (review of Book by Derek Hall, Philip Hirsch and Tania Murray Li). Antipode. -. 2015. Access in a Global Rattan Production Network: A Case Study of Rattan Originating from Central Sulawesi, Indonesia and Upgraded for Sale in International Markets. PhD, University of East Anglia.

Neimark, B., S. Mahanty, and W. Dressler. 2016. Mapping Value in a 'Green' Commodity Frontier: Revisiting Commodity Chain Analysis. Development and Change 47, no. 2: 240-265.

Nightingale, A.J. 2011. Bounding Difference: Intersectionality and the Material Production of Gender, Caste, Class and Environment in Nepal. Geoforum; Journal of Physical, Human, and Regional Geosciences 42, no. 2 (March 1): 153-162.

Oliver, P.E., and G. Marwell. 2001. Whatever Happened to Critical Mass Theory? A Retrospective and Assessment. Sociological Theory 19, no. 3 (November 1): 292-311.

Peters, P.E. 1993. Is "rational Choice" the Best Choice for Robert Bates? An Anthropologist's Reading of Bates's Work. World Development 21, no. 6 (June 1): 1063-1076.

Pedersen, R.H. 2016. Access to Land Reconsidered: The Land Grab, Polycentric Governance and Tanzania's New Wave Land Reform. Geoforum; Journal of Physical, Human, and Regional Geosciences 72: 104-113.

Petitt, A. 2016. Women's Cattle Ownership in Botswana. PhD, Swedish University of Agricultural Sciences.

Polanyi, K. 1945. Origins of Our Time: The Great Transformation. London: Victor Gollancz.

Rao, N. 2008. "Good Women Do Not Inherit Land": Politics of Land and Gender in India. New York: Berghahn Books.

Rasmussen, M.B., and C. Lund. 2018. Reconfiguring Frontier Spaces: Territorialization and Resource Control. World Development 101: 388-399.

Ribot, J. 1998. Theorizing Access: Forest Profits along Senegal's Charcoal Commodity Chain. Development and Change 29: 307-341.

. 2007. Representation, Citizenship and the Public Domain in Democratic Decentralization. Development 50, no. 1 (March 5): 43-49. 
2013. Choice, Recognition and the Democracy Effects of Decentralization. In The Imperative of Good Local Governance: Challenges for the next Decade of Decentralization, ed. J. Öjendal and A. Dellnäs, 93-120. Tokyo: UNU Press.

. 2014. Cause and Response: Vulnerability and Climate in the Anthropocene. The Journal of Peasant Studies 41, no. 5: 667-705.

. 2018. Cause and Responsibility in the Anthropocene: Sociodicy under a Changing Sky. In The Politics of Sustainability -- Rethinking Sustainability, Values and Justice. University of Helsinki. http://jesseribot.com/films.

Ribot, J., A. Chhatre, and T. Lankinad. 2008. Introduction: Institutional Choice and Recognition in the Formation and Consolidation of Local Democracy. Conservation and Society 6, no. 1: 1-11.

Ribot, J., and N.L. Peluso. 2003. A Theory of Access. Rural Sociology 68, no. 2: 153-181.

Rocheleau, D., and D. Edmunds. 1997. Women, Men and Trees: Gender, Power and Property in Forest and Agrarian Landscapes. World Development 25, no. 8 (August 1): 1351-1371.

Rytteri, T., and M. Sawatzky. 2013. Forest Access Regimes: An Analysis of the Time and Space of Forest Use in Southeast Manitoba. Native Studies Review 22, no. 1\&2: 83-112.

Schlager, E., and E. Ostrom. 1992. Property-Rights Regimes and Natural Resources: A Conceptual Analysis. Land Economics 68, no. 3: 249-262.

Scoones, I. 2009. Livelihoods Perspectives and Rural Development. The Journal of Peasant Studies 36, no. 1 (January 1): 171-196.

. 2015. Sustainable Livelihoods and Rural Development. Bourton on Dunsmore: Practical Action Publishing.

Sen, A. 1981. Poverty and Famines: An Essay on Entitlement and Deprivation. OUP Oxford. 1987. Gender and Cooperative Conflicts. WIDER Working Paper 18.

. 1994. Development: Which Way Now? In Paradigms in Economic Development: Classic Perspectives, Critiques, and Reflections, ed. R.K. Kanth, 211-232. London: M.E. Sharpe.

Sikor, T., and C. Lund. 2009. Access and Property: A Question of Power and Authority. Development and Change 40, no. 1: 1-22.

Solesbury, W. 2003. Sustainable Livelihoods: A Case Study of the Evolution of DFID Policy. ODI Working Paper 217.

Sultana, F. 2011. Suffering for Water, Suffering from Water: Emotional Geographies of Resource Access, Control and Conflict. Geoforum; Journal of Physical, Human, and Regional Geosciences 42: 163-172.

Svarstad, H., T.A. Benjaminsen, and R. and Overå. 2018. Power Theories in Political Ecology. Journal of Political Ecology.

Weber, M. 1978. Economy and Society: An Outline of Interpretive Sociology. Oakland: University of California Press.

Weigelt, J. 2014. Reforming Development Trajectories?: Institutional Change of Forest Tenure in the Brazilian Amazon. PhD, Humboldt University of Berlin.

Westermann, O. 2007. Poverty Access and Payment for Watershed Hydrological Services: A Social Feasibility Study with Case in Tiquipaya Watershed Bolivia. PhD, Roskilde University.

Williams, S. 2013. Beyond Rights: Developing a Conceptual Framework for Understanding Access to Coastal Resources at Ebenhaeser and Covie, Western Cape, South Africa. PhD, University of Cape Town.

Wright Mills, C. 2000. The Sociological Imagination. Oxford: Oxford University Press.

Wright, M.W. 2010. Geography and Gender: Feminism and a Feeling of Justice. Progress in Human Geography 34, no. 6 (August 26): 818-827. 